\title{
Kályhacsempék és kályhaszemek a kereki várból
}

\author{
KOCSIS EDIT ${ }^{1}$ és VARGA MÁTÉ \\ ${ }^{1}$ Magyar Nemzeti Múzeum Mátyás Király Múzeuma, H-2025 Visegrád, Fő u. 23., e-mail: kocsisedit@visegradmuzeum.hu \\ ${ }^{2}$ Szegedi Tudományegyetem; Rippl-Rónai Múzeum, H-7400 Kaposvár, Fő u. 10., e-mail: vargamate12@gmail.com
}

\begin{abstract}
Kocsis, E. \& VARGA, M.: Different types of stove tiles from the Kereki castle.

Abstract: Up to these days, there has only been minor investigation on the grounds of the late castle next to Kereki. During the excavations, a small amount of stove tile fragments was found, but the pieces are, however, rather significant. Most of the stove tiles can be traced back to the time of Sigismund of Luxembourg, but stoves were built here in the second half of the 15th century, and even in the 16th century. Based on the findings, a theoretical reconstruction of the tiled stove from the time of Sigismund is also possible.
\end{abstract}

Keywords: medieval, stove, Fehérkő castle, Sigismund of Luxembourg, baronial residence

\section{Bevezetés}

Kereki vára emblematikus a Somogy megyei várak között, hiszen ez a legépebben megmaradt középkori vár a megyében. A várnak - egyedülálló módon - ma is több méter magasan álló kőből, és többnyire téglából épült falai láthatóak. Ugyan már sok Somogy megyei várban folytattak régészeti kutatásokat, a kereki vár területén mindezidáig komolyabb feltárás nem történt. Csak két kisebb kutatást lehet megemlíteni a 20. század derekáról. A vár jelentőségét jelzi az is, hogy a kutatások alkalmával kis mennyiségü, de annál jelentősebb régészeti leletanyag került elő. Ez a tárgyi anyag csak részleteiben került közlésre, ezért jelen tanulmányban először a vár területén előkerült jelentős kályhacsempe és kályhaszem anyagot szeretnénk közölni, remélve, hogy a vár régészeti és múemlékvédelmi kutatása folytatódni fog a közeljövőben, továbbá hozzájárulunk a régió középkori kályhakultúrájának kutatásához is.

\section{Földrajzi környezet és a vár rövid története}

Kereki Somogy megyében, a Balatontól 7 kilométerre fekszik, az egyik legfontosabb balatoni átkelő (Tihany-Szántód) közelében. A vár a mai településtől nyugatra, közvetlenül annak nyugati szélén található. ${ }^{2}$ A középkorban erre haladt a Veszprém-szlavóniai út.

A település első említése 1193-ból való, amikor III. Béla megerősítette a johannita lovagokat birtokaikban, az ő tulajdonuk volt Kereki (Querequi) is. 1229ben mindez már a székesfehérvári káptalan tulajdo-

1 A feldolgozás során nyújtott segítségért köszönet Kiss Viktornak Heczer Brigittának, Csajági Nikolettának, Horváth Péternek és Ujhelyi Nórának. A leletanyag a keszthelyi Balatoni Múzeumban található meg 2015.1.1-29. leltári szám alatt.

2 Lelöhely azonosító: 19569, névváltozatok: Fehérkő (Feyerkew), Kupavár, Katonavár. na. Az 1333-35. közötti években említették a pápai tizedjegyzékekben kereki plébánosát. A vár ekkoriban, 1336-ban tünt fel először az oklevelekben, ekkor még királyi várként. A vár - amelyet Fehérkő váraként is említenek a források - 1396-ban került Marczali Miklós tulajdonába, aki ekkor temesi ispán is volt egészen 1402-ig. ${ }^{3} 1402-03$ között az erdélyi vajda címet is birtokolta, 1409-től somogyi ispán lett, 1408-tól 1413-ban bekövetkezett haláláig pedig a báró és királyi tanácsos cím is megillette. ${ }^{4}$ 1451-ben Kis-, és Nagykerekit is említették. 1467-ben Enyingi Török Péter, majd 1495től a Báthoriak birtoka lett a település, majd 1530-ban Perneszi Ferenchez került. A várat a Marczali család utolsó férfitagjának, Lászlónak a halála után 1474-ben a Báthoriak örökölték meg. Magát a várat egy 1494-es oklevél már romosnak írta le. ${ }^{5} \mathrm{~A}$ török hódítást követően 1551-ben Kereki már biztosan oszmán fennhatóság alatt állt, hiszen a fehérvári szandzsák, kőröshegyi náhiejéhez tartozott. A török kori adóösszeírások alapján ekkor még nem néptelenedett el a falu, de 1563-tól már a törökkoppányi szandzsákhoz tartozott. 1564ben Perneszi Farkas birtokolta névlegesen Kerekit, aki Babócsa várkapitánya volt. 1573-74-ben és 1580-ban még összeírták a település házait és családfőit. 1598ban és 1599-ben szintén említették a települést, azonban a tihanyi vár 1609-es összeírásában már nem, így a település pusztulása/elnéptelenedése e két időpont közé tehető. A törökkoppányi szandzsák 1631. évi öszszeírásában sem szerepelt már a település. 1665-ben Perneszi János eladta kereki birtokrészeit Salomváry Jánosnak. 1695-ben pedig Perneszi Zsigmond adta el itteni birtokait Babócsay Ferencnének. ${ }^{6}$

\section{Kutatástörténet}

A második világháború után, 1959-ben a vár romterületének kitisztítását Dornyay Darnay Béla vezetésével végezték el. Ezt követően a müemlékvédelmi helyreállítások miatt Sági Károly végzett ásatásokat 1961-62-ben. 1962-63-ban Koppány Tibor irányításával elkészültek a vár állagmegóvási és helyreállítási munkálatai. ${ }^{7}$

3 Marczali Miklós testvére Dénes mester, aki ekkoriban visegrádi várnagy.

4 Engel 1996, I. 204, II. 154

5 Koppány 1993, 215.

6 Koppány-Sági 1967, 5-11, 15-17, 22.

7 Koppány-Sági 1967, 3 


\section{A vár}

A Koppány Tibor által közölt helyszínrajzon ${ }^{8}$ egy délről és nyugatról kettős sánccal övezett, szabálytalan sokszög alaprajzú, támpilléres külső fallal körülkerített vár bontakozik ki. A vár bejárata - egy két támpillérre támaszkodó kaputorony - a déli oldalon nyílt. A trapéz alakú várudvart nyugatról, északról és keletről palotaszárnyak vették körül, de a két utóbbi épületszárnyból alig maradt valami. A nyugati oldalon emelkedett a belső torony, a tőle délre futó palotaszárny külső fala még az első emelet magasságáig áll, kívül két támpillér támasztja. Megmaradt az árnyékszék kettős aknája is, amely az első és a második emeletről vezetett az árokba - az első emeleti fülkének a boltozata is megvan. Látható még a nyugati és északi szárnyak alatt húzódó pincébe vezető kőlépcső is félköríves kapukeretével együtt. ${ }^{9}$

A vár a kevés régészeti leletanyag alapján a 14 . században épülhetett, ugyanis ennél korábbi anyag nem került elö. ${ }^{10}$ Sági úgy véli, hogy a várat 1491-es ostroma után már nem használták, a 16. század közepe táján, talán a török hadak közeledtének hírére pedig felrobbantották. ${ }^{11}$

\section{Korábbi közlések a vár kályhacsempéiről}

Sági Károly és Koppány Tibor csak érintölegesen említette a kályhacsempéket. Egyetlen példány (Kat.1.) rajzát közölték, amiröl megállapították, hogy hasonló csak zöld mázzal bevont - mesejelenetes darab ismert a budai várból, és a Kerekiben előkerült példányt is ugyanazzal a préselőmintával gyártották. A kutatás akkori állása szerint ezek a kályhacsempék 1387-1396 között készültek. ${ }^{12}$

További kályhacsempék és kályhaszemek kerültek elő a várfal külső tövében, azonban ezek mind utólagos kincskeresés által bolygatott rétegből származnak. A közlemény szerint előkerült két grafitos anyagú, ausztriai csempe töredéke, amit a 14. századra kelteztek, illetve szintén innen néhány mázas és mázatlan kályhaszem, amiket feltételesen szintén a 14. századra datáltak. ${ }^{13}$

Több kályhacsempe a pince feltöltéséből került elő. Az egyik ilyen a mesejelenetes kályhacsempe, melynek tölgyfalevelei maradtak meg. Ezt akkor a Zsigmond-kori II. csoport 2. típusának tartották. Itt is feltételezték a budai példányokkal közös préselőmintát. Szintén innen került elő egy áttört, mérműves kályhacsempe töredék, amit akkor Holl Imre a Zsigmond-kori II. csoport 14. típusának tartott. Ezek a kályhacsempék már 1408 után készülhettek a nyéki mühelyben, és ezután szállíthatták a fehérkői várba. ${ }^{14}$

8 Koppány 1993, 214

9 Koppány 1993, 213-215

10 Koppány-Sági 1967, 14.

11 Koppány-Sági 1967, 26.

12 Koppány-Sági 1967, 19-20.

13 Koppány-Sági 1967, 20. Véleményünk szerint a kályhacsempék és kályhaszemek nem származhatnak a 14. századból, valószínűleg 16. századot akartak írni.

14 Koppány-Sági 1967, 21. 1403-ban a várnak volt egy kisebb ostroma, ami után szükségessé válhatott a felújitás, és új kályhák építése.
Szintén a pincéből kerültek elő barnássárga színű mázzal fedett töredékek. Az egyiken sárkány farka látható, míg a másikon - Sági véleménye szerint - egy rosszul rajzolt ló hátsó lábai. Ezen kívül sárga mázas, rozettával díszített saroktöredék is került elő. ${ }^{15}$

Sági véleménye szerint az újjáépítés után egy díszes kályha állhatott a várban (kora Zsigmond-kori kályha, talán az I. típus, amit a 14. század végére-15. század elejére lehet keltezni), továbbá másik két helyiségben is lehetett díszes kályha. Továbbá még két egyszerübb szemes kályha darabjai is előkerültek. ${ }^{16}$

\section{A kályhacsempék}

Az eddig összegyüjtött kályhacsempe anyag igen töredékes és csekély mennyiségü, azonban a töredékek túlnyomó többsége mégis egy adott korszaknak és egy kályhás mühelynek a terméke. Mivel Holl Imre megnevezése szerint a Zsigmond-kori I. mühely számos más helyen is készített kályhát ebben a korban, ezekből a kis töredékekből több csempetípust is lehet azonosítani, és az egykori kályha felépítését is nagyjából rekonstruálni lehet. Ez azért is fontos, mert egyre tisztább képet kezdünk alkotni a középkori kályhásmühelyeink tevékenységi köréröl, s arról is, mekkora területen és milyen társadalmi körben használták ezeket a reprezentatív fütőberendezéseket.

\section{A vár területéről eddig előkerült, beazonosítható csempetípusok}

\section{Egy Zsigmond-kori I. mühely kályhájának darabjai}

1. Mesejelenetes négyzetes csempe nyuszival és sünnel egy nagy tölgyfa alatt, a Zsigmond-kori I. csoport 2. típusa. ${ }^{17} 1 \mathrm{db}$ drapp színú mázatlan kerámia, éles rajzolatú lenyomattal, valamint $3 \mathrm{db}$ csempe töredéke sárgásbarna mázzal. Feltételezett mérete kb. $26 \times 26 \mathrm{~cm}$ (1-3. ábra).

2. Heraldikailag balra ágaskodó, kettős farkú cseh oroszlánt ábrázoló négyzetes csempe, Zsigmond-kori I. csoport 11. típus. ${ }^{18} 1 \mathrm{db}$ töredék barnássárga mázzal. Feltételezett mérete kb. $26 \times 26 \mathrm{~cm}$ (4. ábra 1-2.).

3. Négyzetes csempe valamilyen sárkánylábbal, illetve háti tüskékkel, egy heraldikailag balra néző sárkányrendes ábrázolás részlete lehet. $2 \mathrm{db}$ töredék barnászöld mázzal, valószínüleg egy csempe darabjai (5. ábra).

4. Dongás hátú félcsempe, előlapján középen szőlőfürttel és indákkal, a sarkokban 5-6 gömböcskéböl álló halmazzá redukálódott levélkékkel, Zsigmond-kori I. csoport 26. típus. ${ }^{19} 1 \mathrm{db}$ töredék barnászöld mázzal (6. ábra).

5. Összeépített sarokcsempe négyzetes csempéből és félcsempéből összeillesztve, közös hátrész kialakítással, az előlapok letörtek. 1 db töredék, zöld mázzal.

\footnotetext{
15 Koppány-Sági 1967, 21.

16 Koppány-Sági 1967, 21.

17 Holl 1958, 228, 30. kép.

18 Holl 1971, 163, 114. kép.

19 Holl 2002, 357-358.
} 


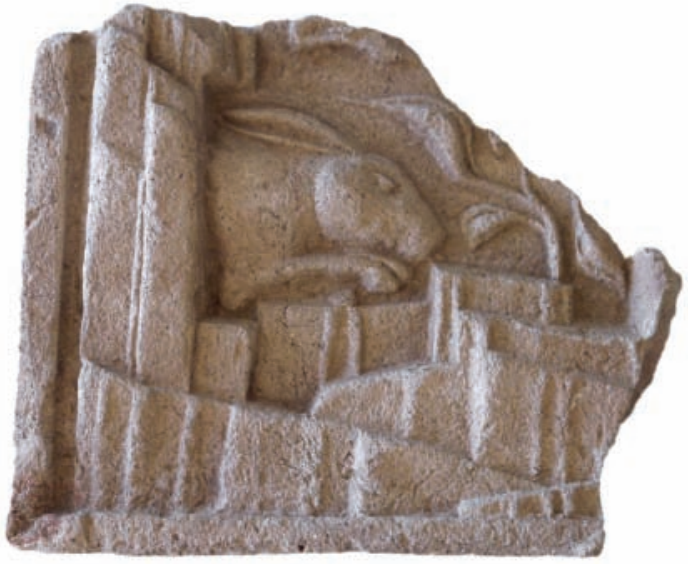

1. ábra. Zsigmond-kori mesejelenetes kályhacsempe töredéke.

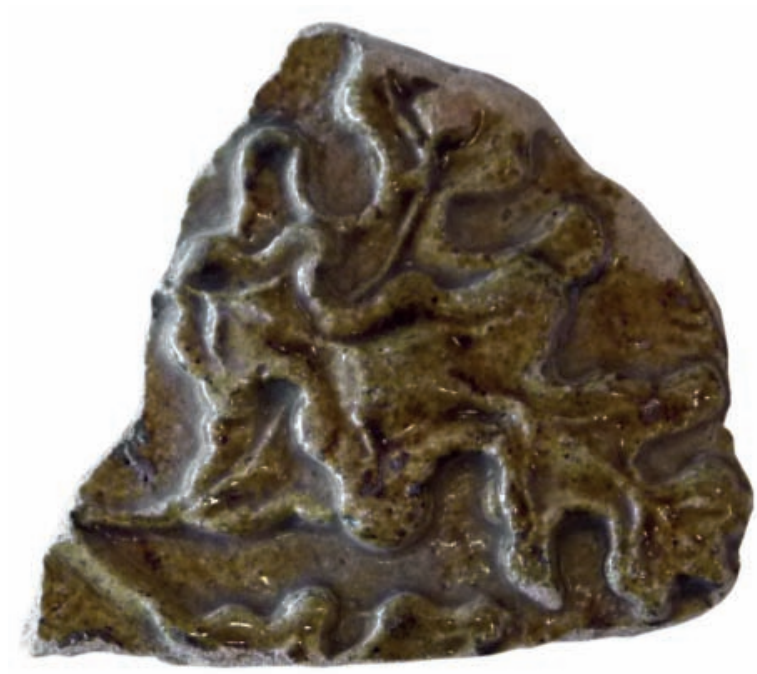

3. ábra. Zsigmond-kori mesejelenetes kályhacsempe töredéke.

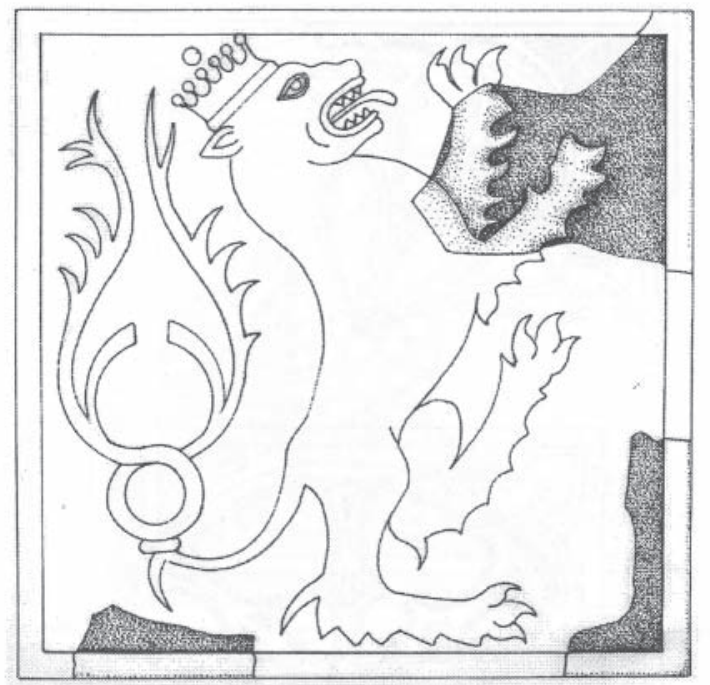

4.2. ábra. A kályhacsempe analógiájának rajza az esztergomi érseki palotából (Boldizsár Péter nyomán).

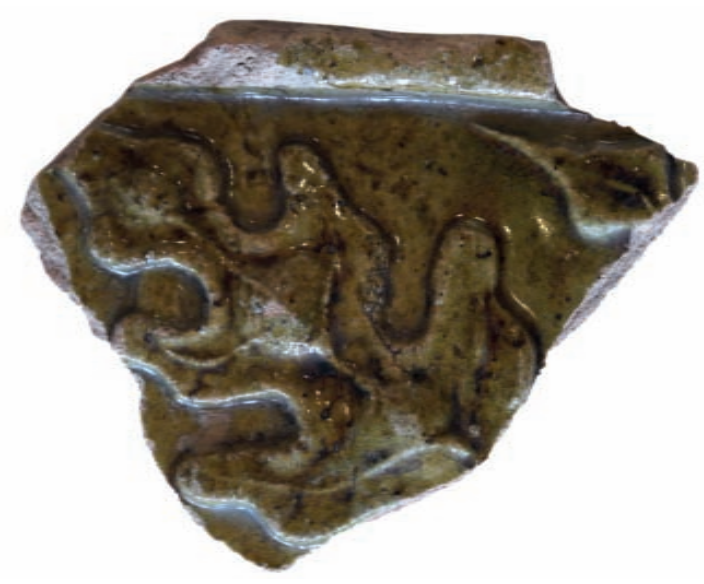

2. ábra. Zsigmond-kori mesejelenetes kályhacsempe töredéke.

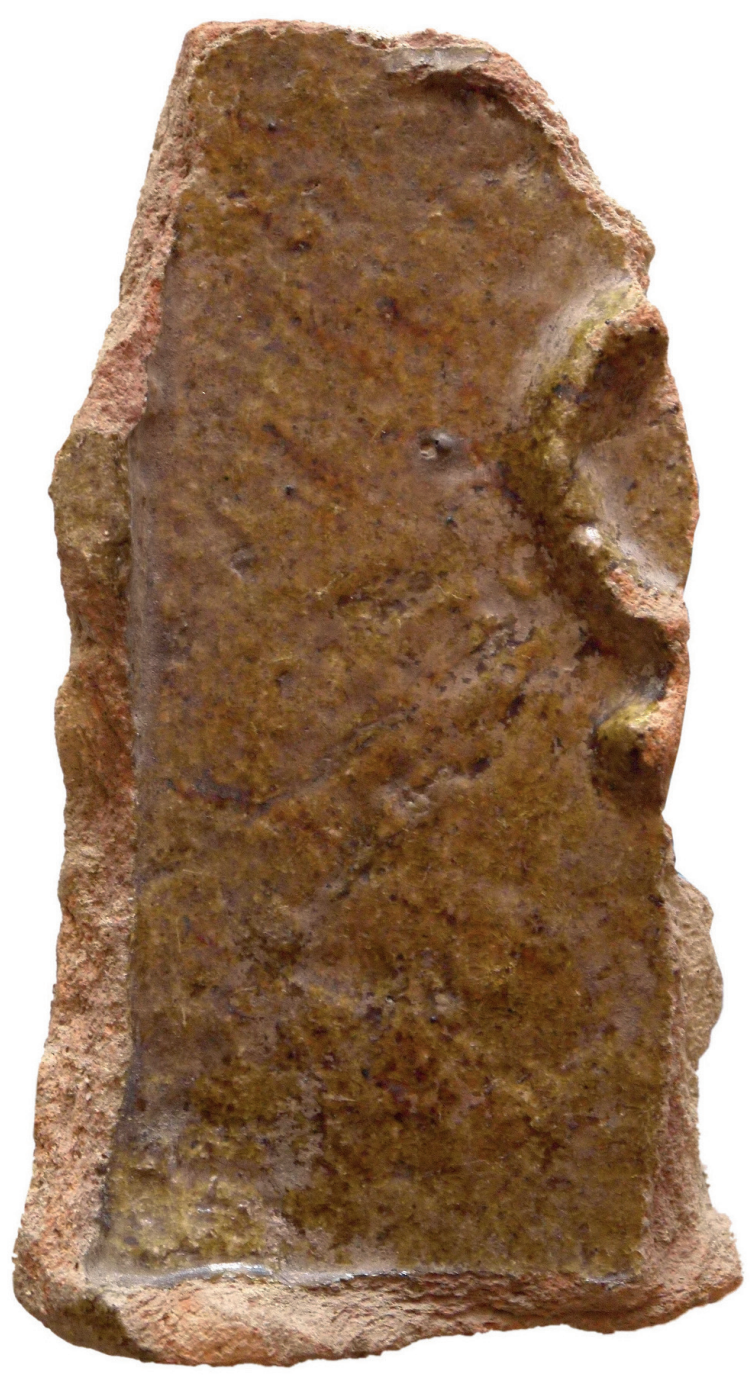

4.1. ábra. Zsigmond-kori kettős farkú cseh oroszlánt ábrázoló kályhacsempe töredéke. 


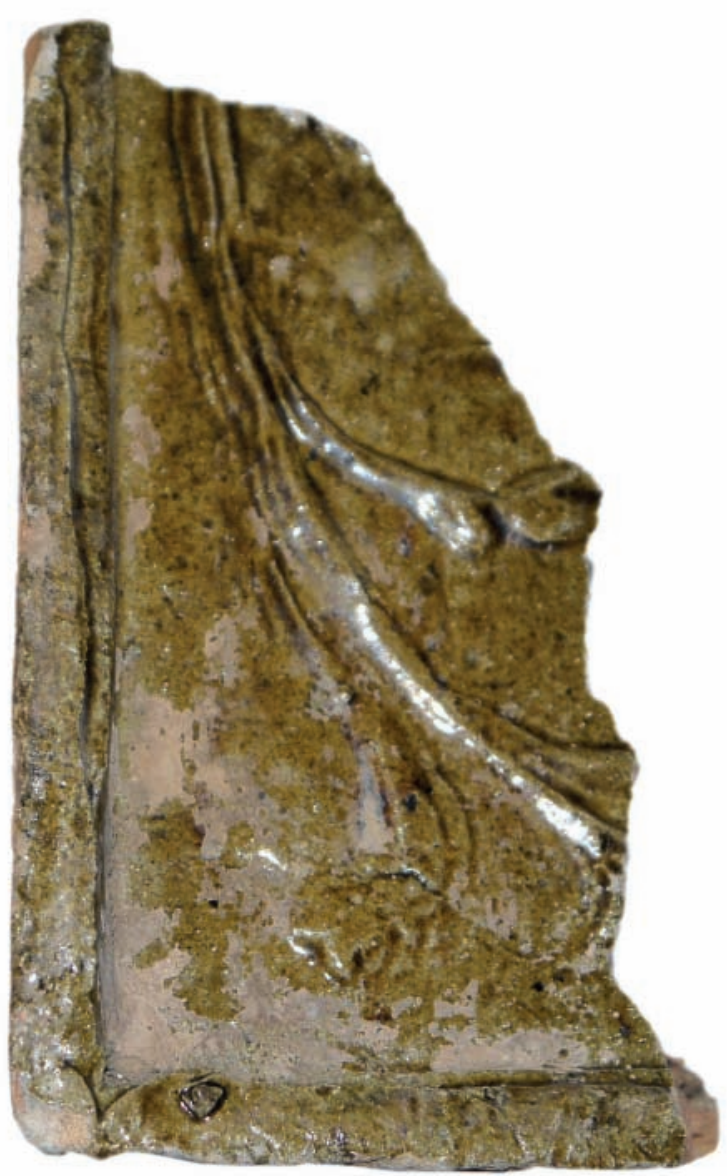

5. ábra. Zsigmond-kori sárkányrendes ábrázolású kályhacsempe töredéke.

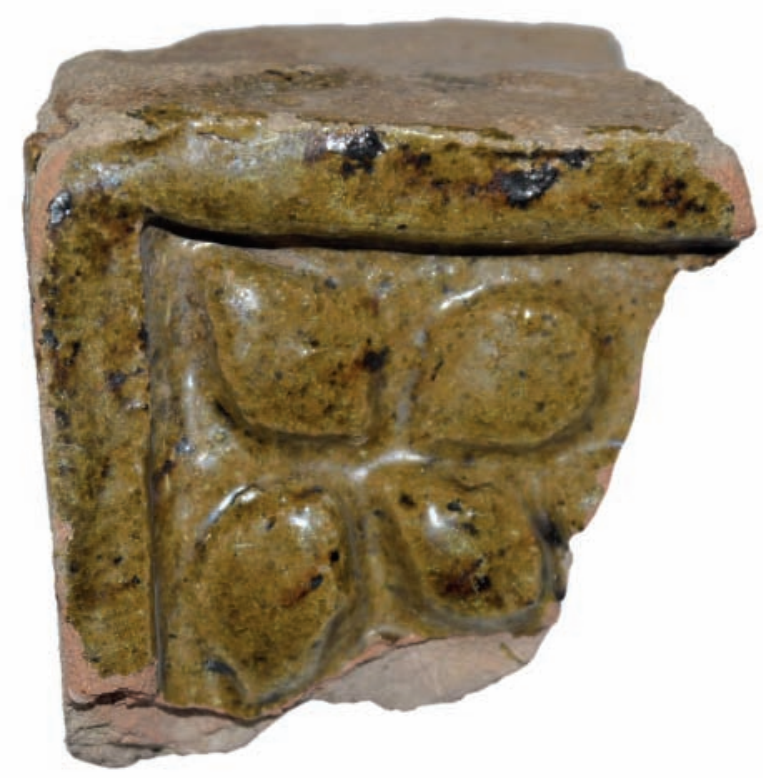

6. ábra. Zsigmond-kori szőloofürtös és indás kályhacsempe töredéke.

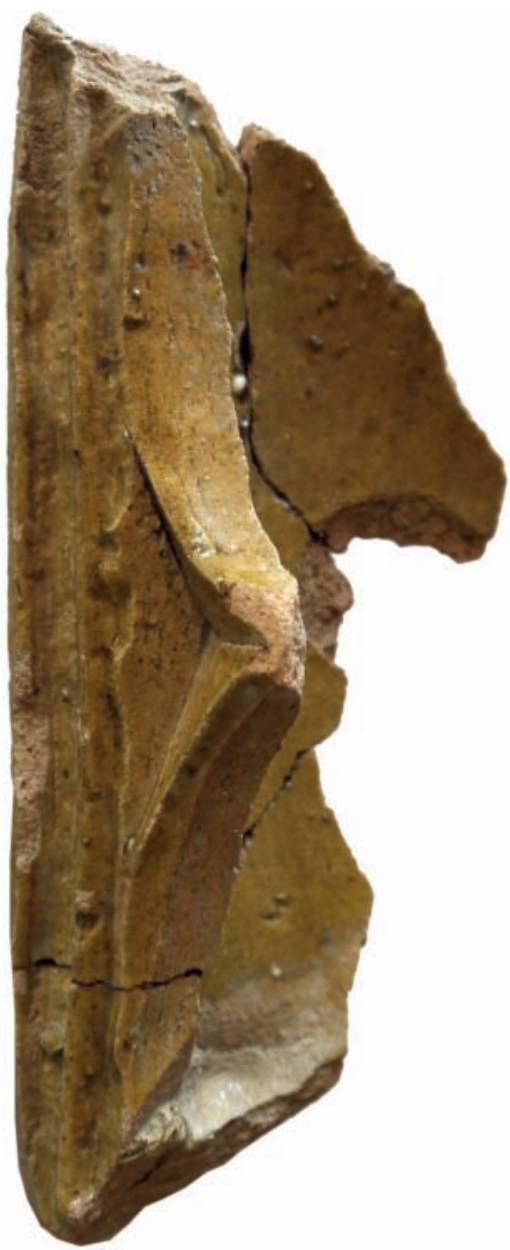

7. ábra. Zsigmond-kori áttört elölapú, négykaréjos, élbefutó profilú mérmüves kályhacsempe töredéke.

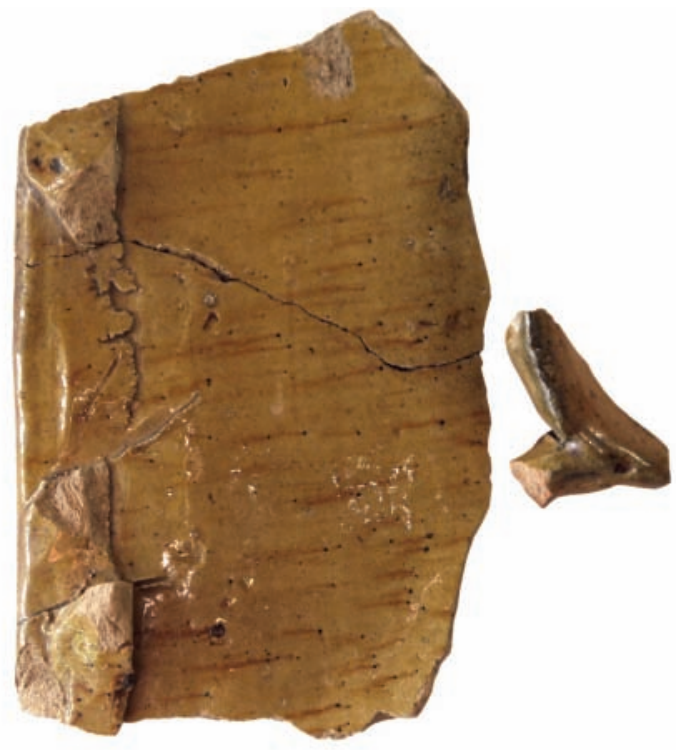

8. ábra. Zsigmond-kori áttört elölapú, aszimmetrikus mérmüdíszitésü, élbefutó mérmü profilú kályhacsempe töredéke. 
6. Négyzetes alakú, áttört előlapú csempe töredékei négykaréjos, élbefutó profilú mérmü díszítéssel. 3 $\mathrm{db}$ töredék maradt meg, amely két csempéhez tartozhat. Feltételezett élhossz: 22-22,5 cm, a tál alakú hátrész mélysége $9 \mathrm{~cm}$ (7. ábra).

7. Négyzetes alakú, áttört elölapú csempe aszimmetrikus mérmű díszítéssel, élbefutó mérműprofillal. $1 \mathrm{db}$ töredék sárga mázzal, benne barna vasoxid cirmokkal (8. ábra).

8. Téglalap alakú, nagyméretű csempe töredéke dongás hátkialakítással, előlapján talán egy címerábrázolás csöbörsisakjának töredéke látható, illetve valamilyen sisaktakaró részlete. $1 \mathrm{db}$ töredék barnássárga mázzal (9. ábra).

9. Téglalap alakú zárt előlapú csempe, vakmérmüves mintával, pálcás mérmüprofillal. A csempe felső részén körbe írt forgó halhólyagos díszítés, a csempe felső sarkaiban háromkaréjos térkitöltés. $1 \mathrm{db}$ töredék barnássárga mázzal (10. ábra).

10.Téglalapalakúzártelőlapúcsempevakmérműves mintával, hármas tagolású mérmüprofillal, a Zsigmondkori I. csoport $6 / \mathrm{b}$ típus ${ }^{20}$ át nem tört változata. A körbe írt vakmérmü közepén ötkaréjos rozetta látható. $1 \mathrm{db}$ töredék barnássárga mázzal (11. ábra).

11. Téglalap alakú, zárt vagy félig áttört előlapú csempe. $1 \mathrm{db}$ töredék sötétzöld mázzal.

12. Hagyma alakú kályhaszemek a kályha kupolájából. 4 db hagyma alakú kályhaszem darabjai, felül sötétzöld mázzal. Magasságuk 14,7-15 cm, legnagyobb átmérőjük 14 cm, száj átmérőjük kb. 10 cm (12. ábra).

\section{Szürke, redukált égetésü szemeskályha a 15. század második feléből}

1. Sarok kályhaszem négyszögletes tál alakú szemből és korongolt félhengeres kályhaszemből összeépítve. A sarokélre illesztve agyagcsík fut végig, amelyen egyenetlen bevagdalással kötélfonatot imitáltak. A kötélfonat két oldala mentén kétfelé osztott halszálkamintás díszítés fut végig, amelyet pecsétlőhengerrel nyomtak bele a még puha agyagba. A pecsétlőhenger minta ismétlődési hossza $4,7 \mathrm{~cm}$, szélessége $0,6 \mathrm{~cm}$. A sarokelem magassága $22 \mathrm{~cm}$, a szélesebb oldal $22+2 \mathrm{~cm}$, a keskenyebb oldal kb. $11 \mathrm{~cm}$ széles. A kályha négyszögletes tál alakú csempéinek oldalhossza kb. $22 \mathrm{~cm}$ lehetett. A kályhaszemek a felületükön fakó, sötétszürke színűek, a törésfelületük kissé világosabb szürke színü (13-14. ábra).

\section{Egyéb kályhaszemek (16. század)}

1. Hagyma alakú kályhaszemek csúcsos tetővel, a csúcs alatt egy-egy körbefutó horonnyal díszítve. Homokos soványítású, barnára égetett kerámia, mázatlan, $2 \mathrm{db}$ töredék, legnagyobb átmérőjük $11-11,5 \mathrm{~cm}$.

2. Hagyma alakú kályhaszem. Homokos soványítású, vörösre égetett kerámia, 1 db töredék.

3. Négyszögletes tál alakú kályhaszem csücskösre alakított sarkokkal. $1 \mathrm{db}$ töredék élénkvörösre égetett kerámiából, belseje egykor grafitozva lehetett.

20 Holl 1958, 228, 33. kép b.

\section{A Zsigmond-kori csempék anyaga}

A Zsigmond-kori I. csoporthoz tartozó kályhacsempék anyaga kissé porózus felületü, általában drapp színűre, egyes részeken rózsaszínre/vörösre égetett kerámia. A kerámia néhol rétegesen égett át, törésfelületében belül néha egy szürkére vagy rózsaszínre égett csík figyelhető meg. A hátrészekhez felhasznált agyag kevésbé volt finomra iszapolva, benne gyakran beleégett zárványok láthatóak. A kályhásmester készített mázatlan csempét is, de a legtöbb darabon barnássárga, sárgásbarna, zöldesbarna vagy sötétzöld ólommáz található. Némelyik sárgás mázú csempén barna vasoxid pettyek és cirmok is láthatók, mivel a vasoxid szemcséket nem keverték el egyenletesen a mázban. A különböző sárgás-barnás, illetve zöldes árnyalatú csempék keverten fordulhattak elő a kályhán, de a kupola hagyma alakú kályhaszemeiből eddig csak sötétzöld árnyalatú darabok kerültek elő.

\section{A Zsigmond-kori kályha felépítése}

A zárt előlapú négyzetes csempék egyszerü léckerettel és simán lemetszett végü, fiókos hátrésszel készültek. A körülbelül 22 csempe töredékéböl 12 csempe típust lehetett elkülöníteni. A négyzetes, zárt előlapú, $26 \times 26$ centiméteres csempék, a sarokcsempék és a falhoz illeszkedő félcsempe elemek a kályha alsó, tüzteret körbevevő, nagyjából kocka alakú részét építhették fel. A négyzetes csempék ábrázolásai között volt tölgyfa alatt nyulat és sünt ábrázoló mesejelenet, cseh oroszlános ábrázolás és sárkányrenddel körülölelt címeres csempe is. A félcsempék egyik mintája szőlőfürtös díszítésű volt. A valamivel kisebb, 22-22,5 centiméteres oldalhosszú négyzetes, áttört mérműves előlapú csempék a kályha vállrészénél talán egy átvezető sort alkothattak a felső rész felé. A kályha felső részéből eddig csak téglalap alakú, zárt előlapú, címerdíszes vagy vakmérmüves csempék töredékei maradtak ránk. $A z$ oromcsempék milyenségéről sajnos még ennyit sem tudunk. A kályha kupoláját viszont a kor divatjának megfelelően hagyma alakú kályhaszemek díszítették.

\section{Párhuzamok, következtetések}

Az eddig napvilágra került csekély anyagban a jól elkülöníthető csempetípusok közül négyet lehetett azonosítani a Zsigmond-kori I. csoport mühelyének termékeivel. Ez a hosszú ideig tevékenykedő kályhásmühely nemcsak a királyi udvar számára készített fütőberendezéseket. Holl Imre több müvében ${ }^{21}$ is foglalkozott ennek a mühelynek a termékeivel, újabb és újabb típusokat sorolva ide, végül egy külön cikkben foglalta össze e műhely tevékenységi körét és idejét. ${ }^{22}$

A kályhásmühely még a Zsigmond-kor elején, az 1390-es években kezdhette meg működését, de kályhákat gyártott még az 1410-es években is. Időközben egyes préselőmintái egészen elkoptak - ez látszik né-

21 Holl 1958, 228-231; Holl 1971, 161-166; Holl 1985, 211-215 Holl 1990, 76-77; Holl 2002, 357-380; Holl 2010, 726-740. 22 Holl 2002, 357-380. 


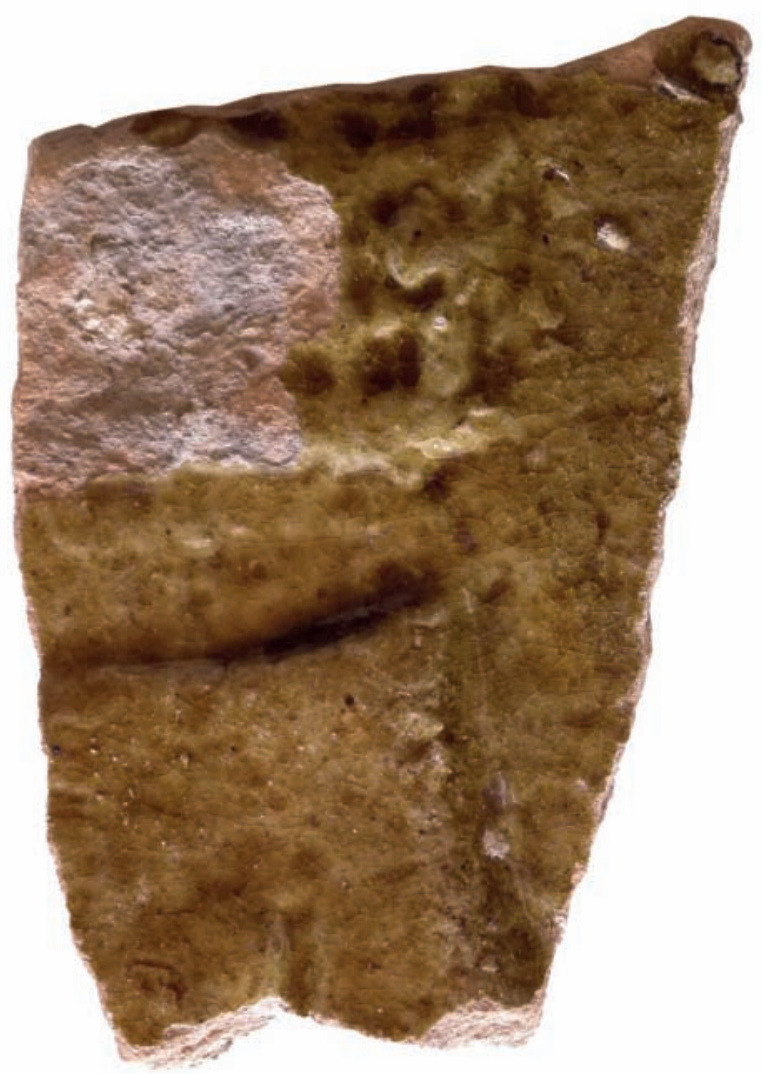

9. ábra. Zsigmond-kori címerábrázolásos kályhacsempe töredéke.

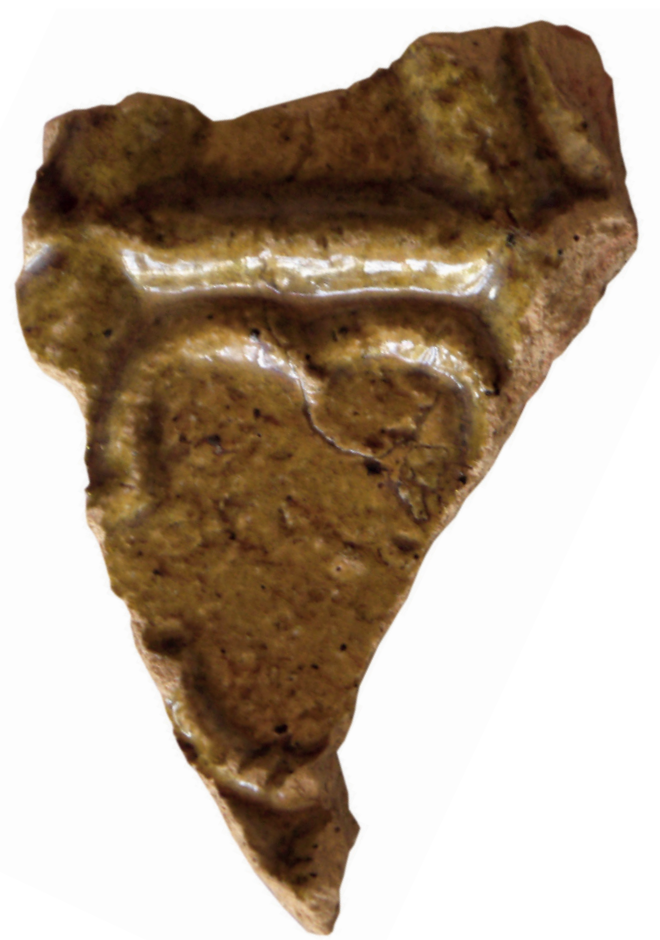

11. ábra. Zsigmond-kori zárt elölapú vakmérmüves kályhacsempe töredéke.

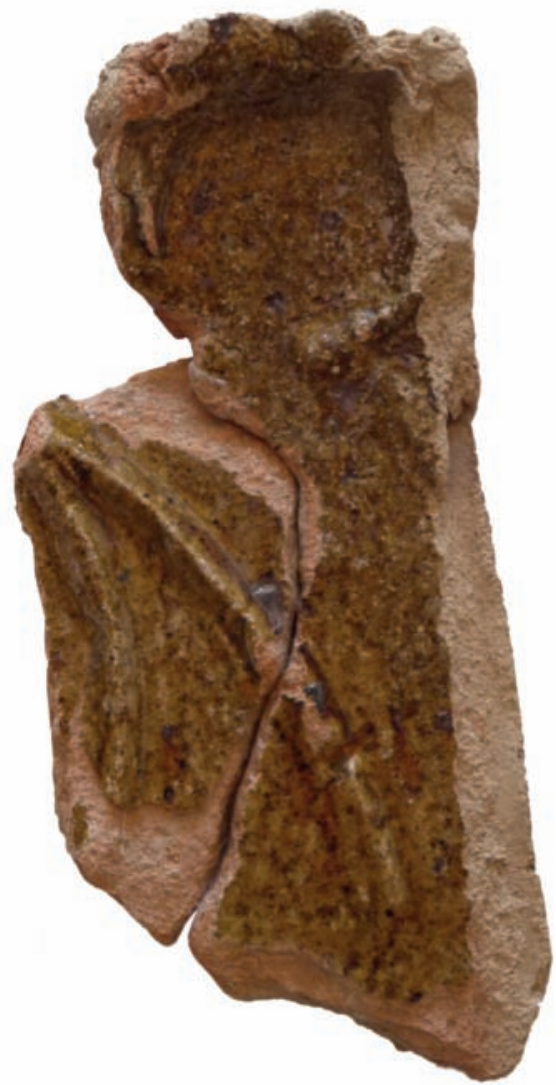

10. ábra. Zsigmond-kori zárt elölapú vakmérmüves kályhacsempe töredéke.

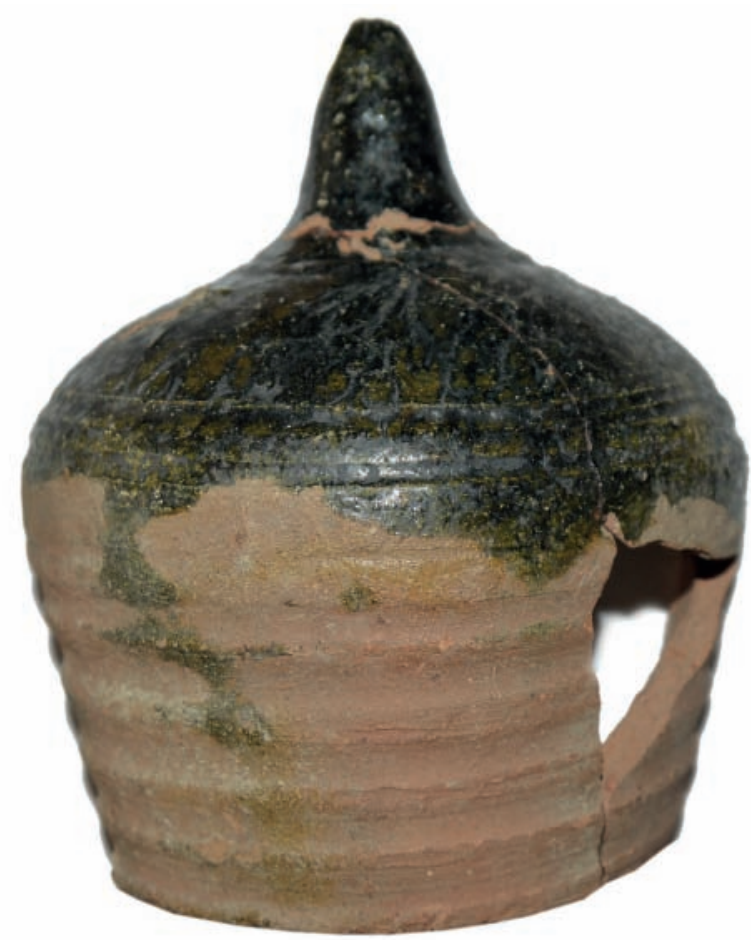

12. ábra. Zsigmond-kori mázas, hagyma alakú kályhaszem töredéke. 


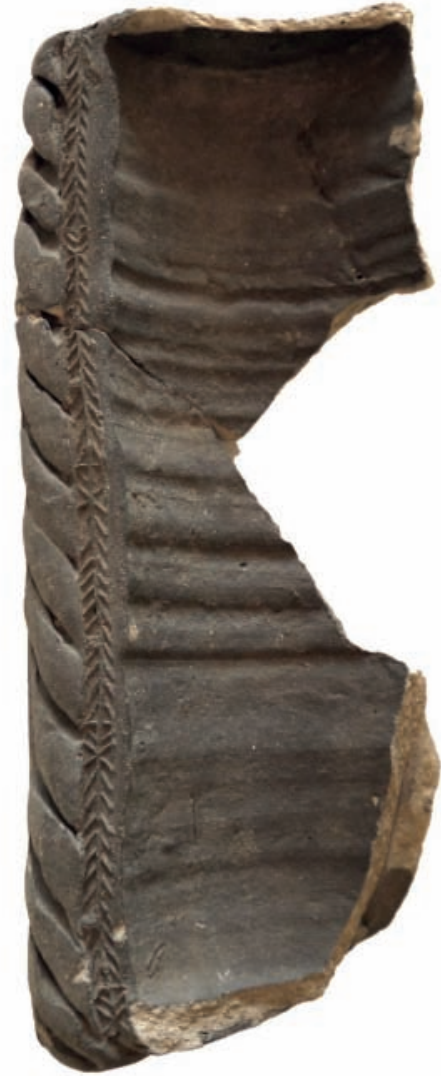

13. ábra. Szürke, redukált égetésü kályhaszem töredéke.

mely elmosódott lenyomatú csempéjükön is -, sőt egyes negatívokat időközben újrafaragott darabokkal pótolhattak. A mühely negatívkészlete folyamatosan gyarapodott is: az idők folyamán az uralkodó újabb címer változatai tűntek fel, egyes darabokon a Sárkány Lovagrend jelvényét is ábrázolták, sőt már a királyhoz közelálló főurak (pl: Eberhard zágrábi püspök, ${ }^{23}$ Cillei család) címerábrázolásai is felbukkantak a csempék elölapján. Az elterjedési kör a királyi központok mellett (azokat is beleértve), nagyjából a Dunántúl északi felére terjedt ki. Az eddig ismert csempék lelöhelyei a következők:

Buda, királyi palota

Nyék, királyi vadászkastély

Visegrád, királyi palota

Buda, város

Pest, város

Esztergom, érseki palota

Vértesszentkereszt, bencés apátság

Pilisszentkereszt, ciszterci apátság

Székesfehérvár

Várgesztes, vár

Várpalota, vár

Kőszeg, vár

Solymár, vár

Kereki, vár

Nándorfehérvár, vár

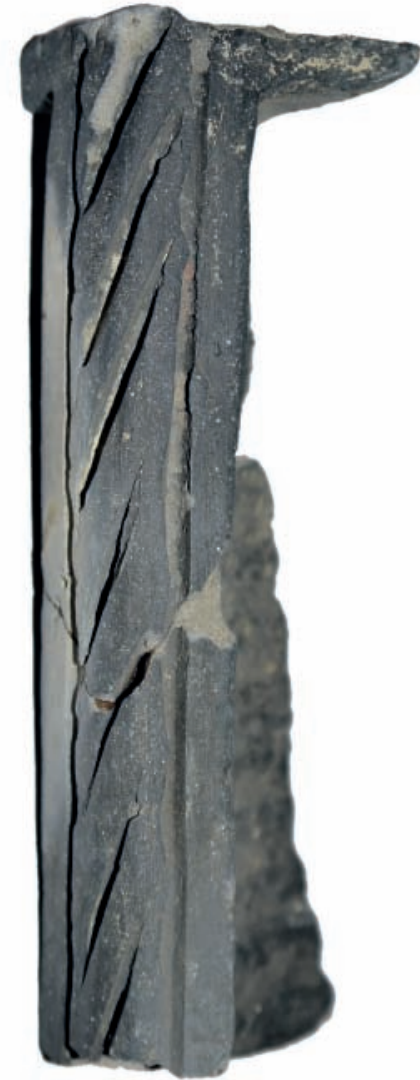

14. ábra. Szürke, redukált égetésü kályhaszem töredéke.

Amint láthatjuk, már Holl Imre is számításba vette a Kereki várából előkerült leleteket, bár csak az addig egyedül publikált mesejelenetes csempetípussal számolt.24 $A$ helyszínek, ahol a Zsigmond-kori I. mühely kályhái álltak részben királyi paloták és vadászkastélyok (Buda, Visegrád, Nyék, Solymár), valamint olyan kolostorok, ahol az uralkodó vadászatai során gyakran megszállhatott (Vértesszentkereszt, a pilisi ciszterci kolostor). Ugyanakkor a kályhák megjelentek egyes udvari bárók városi házaiban (pl. Budán a Lackfiak háza), vagy vidéki rezidenciáiban is: így a Garaiaknak Kőszegen, az Újlakiaknak Várpalotán, a Marczaliaknak Kereki várában volt a mühelytől származó fütőberendezésük. Ez utóbbi rezidencia esetében a várat 1396-tól megszerző és 1413-ban bekövetkezett haláláig birtokló Marczali Henrik lehetett a kályha vagy kályhák megrendelője. Az ő élete és itteni birtoklása szinte egybeesik a kályhásműhely tevékenységi idejével. $A$ kályhán megjelenő sárkányrendes címeres csempét is figyelembe véve, a kályha felállítására 1408 után kerülhetett már sor.

\section{Későbbi szemeskályhák}

A vár anyagából ismertté vált egy igen szépen kidolgozott sarok kályhaszem típus is, négyszögletes tál alakú és félhengeres szemből összeépítve, sarokélén kötélfonat mintával, amelyet kétoldalt pecsétlőhengerrel benyomott

23 Budán, Esztergomban, Várgesztesen is. Holl 1971, 165. 119. kép; Boldizsár 2003, 108. III. tábla 5.; Kovács 2014, 236., Abb. 13.6. 
mintasor kísér. Az ilyen finoman kidolgozott sarokelemek olyan szépen rakott szürke, mázatlan szemeskályhákhoz szoktak tartozni, amelyek elsősorban négyszögletes tál alakú elemekből épültek fel a díszesebb gótikus kályhák mintájára és a kevésbé reprezentatív helyiségeket fütötték. A szemeskályha még a 15. század második felében, a vár romossá válása előtt készülhetett.

Néhány sárgás anyagú, mázatlan, négyszögletes tál alakú, illetve hagyma alakú kályhaszem is előkerült a vár területéről. Ezek már a 16. század folyamán, a zavaros időkben állított szemeskályhákhoz tartozhattak, s nem nagyon különböztek a korabeli falusi szemeskályháktól. Talán a 16. század első felében a már elhagyott vár egy még lakható részét használta valaki, s készíttethette ide ezt az egyszerü szemeskályhát.

\section{Katalógus}

\section{Kályhacsempék}

1. Zsigmond-kori I. csoport, mesejelenetes kályhacsempe saroktöredéke. Drapp színü, porózus anyagú, jól iszapolt, jól égetett, mázatlan, éles lenyomatú, belső oldalán használatra utaló koromnyomok. Eredeti mérete $26 \times 26 \mathrm{~cm}$ lehetett. A mesejelenet bal alsó - szikla és nyuszi - része van meg. $\mathrm{H}: 11,5 \mathrm{~cm}$, sz: $13,8 \mathrm{~cm}$, v: 0,8-1,2 cm, Itsz: 79.400.1. - két udvari járószint közötti töltésből

2. Zsigmond-kori I. csoport, mesejelenetes kályhacsempe peremtöredéke. Drapp színű, jól iszapolt, jól égetett, éles lenyomatú, barnássárga színü mázzal. Eredeti mérete $26 \times 26 \mathrm{~cm}$ lehetett. A mesejelenet tölgylevelei vannak meg. $\mathrm{H}: 10,3 \mathrm{~cm}$, sz: $8,2 \mathrm{~cm}$, v: 0,8-1,1 cm, Itsz: 2015.1.1.- Dornyay Béla gyűjtése, 1959.

3. Zsigmond-kori I. csoport, mesejelenetes kályhacsempe előlapjának töredéke. Drapp színű, jól iszapolt, jól égetett, éles lenyomatú, barnássárga színű mázzal. Eredeti mérete $26 \times 26 \mathrm{~cm}$ lehetett. A mesejelenet tölgylevelei vannak meg. $\mathrm{H}: 9,7 \mathrm{~cm}$, sz: $8,5 \mathrm{~cm}$, v: 0,6-1,1 cm, Itsz: 2015.1.2. - Dornyay Béla gyűjtése, 1959.

4. Zsigmond-kori I. csoport, mesejelenetes kályhacsempe peremtöredéke. Drapp színü, belül rózsaszín, jól iszapolt, rosszul égetett, barnássárga, kicsit zöldes színú mázzal, plasztikus kialakítású, belül használatra utaló koromnyomok. Eredeti mérete $26 \times 26 \mathrm{~cm}$ lehetett. A mesejelenet alsó-középső sziklái vannak meg. $\mathrm{H}: 9,4 \mathrm{~cm}$, sz: $3 \mathrm{~cm}$, mé: $5,2 \mathrm{~cm}$, v: 0,8-1,2 cm, Itsz: 2015.1.6. - ásatásból, 7. zacskó

5. Zsigmond-kori I. csoport, sárkányrendes vagy címeres kályhacsempe saroktöredéke. Drapp színú, jól iszapolt, jól égetett, belül használatra utaló koromnyomok, sárgásbarna színű mázzal. Négyzetes alakú csempe lehetett, a csempén néhány karom/tüske látszik. H: $11,3 \mathrm{~cm}$, sz: $5,8 \mathrm{~cm}$, mé: $4,7 \mathrm{~cm}$, v: 0,6-1 cm, Itsz: 2015.1.7. - ásatásból, 7. zacskó

6. Zsigmond-kori kályhacsempe peremtöredéke. Vörös színű, belül szürkére égett, keményebb kerámia, jól iszapolt, rosszul égetett, a hátrészébe zárványok égtek, barnászöld színű mázzal, belül használatra utaló koromnyomok. Téglalap (?) alakú, sárkányos csempe töredéke lehetett. $\mathrm{H}: 8,6 \mathrm{~cm}$, sz: $5,5 \mathrm{~cm}$, v: 0,8-1,1 cm, Itsz: 2015.1.8. - ásatásból, 7. zacskó
7. Zsigmond-kori I. csoport, sárkányrendes kályhacsempe peremtöredéke. Vörös színü, belül szürkére égett, keményebb kerámia, jól iszapolt, rosszul égetett, aminek a hátrészébe zárványok égtek, barnászöld színủ mázzal, belül használatra utaló koromnyomok. Téglalap alakú lehetett, jobbra néző sárkányos csempe, a sárkány tüskéi vannak meg a bal keret mentén, talán összetartozhat az 5. számú csempével. H: 9,3 cm, sz: 3,1 cm, mé: $9 \mathrm{~cm}$, v: 1,1-1,2 cm, Itsz: 2015.1.9. - ásatásból, 7. zacskó

8. Zsigmond-kori kályhacsempe saroktöredéke. Vörös színű, belül szürke, jól iszapolt, rosszul égetett, kemény csengésű, hátrészében zárványok, zöld színü mázzal, használatra utaló koromnyomok. Négyzetes alakú volt, lelógó címertakaró cafrangjai vagy sárkány farkának töredéke látszik. $\mathrm{H}: 12,9 \mathrm{~cm}$, sz: $7 \mathrm{~cm}$, mé: 8,9 cm, v: 0,8-1 cm, Itsz: 2015.1.3. - ásatásból, 7. zacskó

9. Zsigmond-kori I. csoport, cseh oroszlános kályhacsempe saroktöredéke. Drapp/vörös színü, porózus anyagú, jól iszapolt, jól égetett, barnászöld színű mázzal, Téglalap alakú lehetett, jobbra néző cseh oroszlánnak a kettős farkának egy részlete látható. $\mathrm{H}$ : 12,8 cm, sz: 6,5 cm, v: 0,7-0,9 cm, Itsz: 2015.1.10. - ásatásból, 7. zacskó

10. Zsigmond-kori I. csoport kályhacsempe elölapjának töredéke. Drapp színü, jól iszapolt, jól égetett, barnássárga színü mázzal. Téglalap alakú volt, zárt előlapú, dongás hátú. Csöbörsisak és sisaktakaró ábrázolása látható talán rajta. $\mathrm{H}: 11,3 \mathrm{~cm}, \mathrm{sz}: 8,2 \mathrm{~cm}$, v: 1,1-1,2 cm, Itsz: 2015.1.11. - ásatásból, 7. zacskó

11. Négyzetes alakú kályhacsempe fiókos hátrésze, a vége simán lemetszett. Drapp színủ, belül rózsaszín csík, jól iszapolt, rosszul égetett, kívül lefolyt barnássárga színủ mázzal, belül használatra utaló koromnyomok, 2 db töredék. H: 8,7; 6,8 cm, sz: 7,1; 8,1 cm, v: 0,7-1,2 cm, Itsz: 2015.1.15. - ásatásból, 6. zacskó

12. Négyzetes alakú kályhacsempe fiókos hátrésze, talán áttört. Drapp színű, jól iszapolt, jól égetett, sárga, barna cirmos színü mázzal, kívül használatra utaló koromnyomok. H: 3,7 cm, sz: 7,1 cm, v: 0,8-0,9 cm, Itsz: 2015.1.16.

13. Négyzetes alakú kályhacsempe fiókos hátrésze. Drapp színü, jól iszapolt, jól égetett, sárga, barna cirmos színű mázzal, a máz a külső oldalára is ráfolyt. $\mathrm{H}: 13 \mathrm{~cm}, \mathrm{sz}:$ 9,6 cm, v: 0,8-1,1 cm, Itsz: 2015.1.27.

14. Félcsempe saroktöredéke, dongás háttal. Drapp színü, belül rózsaszín csíkkal, jól iszapolt, roszszul égetett, barnászöld mázzal, belül használatra utaló koromnyomok. Az előlapon középen szőlőfürt és inda volt, a levelek már 5-6 gömböcskévé vannak torzulva. Négy levél van meg a jobb alsó vagy bal felső sarokból. H: $7 \mathrm{~cm}$, sz: $6,9 \mathrm{~cm}$, mé: $7,5 \mathrm{~cm}$, v: 0,6-0,9 cm, Itsz: 2015.1.5. - Dornyay Béla gyűjtése, 1959.

15. Összeépített sarokcsempe peremtöredéke. Hátrész és a keret (?) félcsempe oldaláról. Fiók közös, a vége visszahajtott, lekerekített, visszanyomott (?). A félcsempe előlapja letörött. Drapp színű, rózsaszín csíkkal, jól iszapolt, rosszul égetett, sötétzöld mázzal, belül használatra utaló koromnyomok. $\mathrm{H}: 14,2 \mathrm{~cm}$, sz: 2,1 cm, mé: 5,2 cm, Itsz: 2015.1.17. - ásatásból, 6. zacskó 
16. Négyzetes alakú, 4 karéjos, áttört elölapú kályhacsempe saroktöredéke. Drapp színü, rózsaszín csíkkal, jól iszapolt, rosszul égetett, barnássárga színű mázzal. Az eredeti mérete $22-22,5 \times 22-22,5 \mathrm{~cm}$ lehetett, mélysége $9 \mathrm{~cm}$. Léckeretes, belül pálca keret, ez alatt mérmü, késsel metszett. $\mathrm{H}: 7,7 \mathrm{~cm}$, sz: $2,7 \mathrm{~cm}$, mé: $8,1 \mathrm{~cm}$, v: 0,7-0,9 cm, Itsz: 2015.1.4. - ásatásból, 6. és 1. zacskó

17. Négyzetes alakú, áttört elölapú, mérműves kályhacsempe oldaltöredéke, és tál alakú hátrésze. Nem szimmetrikus mérmű, élbefutó profil. Drapp színü, jól iszapolt, jól égetett, sárga, barna cirmos színű mázzal, külső felületén használatra utaló koromnyomok. H: $21,4 \mathrm{~cm}$, sz: $5,2 \mathrm{~cm}$, mé: $10,5 \mathrm{~cm}$, v: 0,6-0,8 cm, Itsz: 2015.1.18.- ásatásból, 6. és 2. zacskó

18. Négyzetes alakú, áttört elölapú, mérműves kályhacsempe oldaltöredéke, és tál alakú hátrésze. Nem szimmetrikus mérmű, élbefutó profil, és egy darab orrtag töredéke, élbefutó profillal. Drapp színű, jól iszapolt, jól égetett, sárga-barna cirmos színű mázzal, külső felületén használatra utaló koromnyomok. $\mathrm{H}$ : 14,$7 ; 4,5 \mathrm{~cm}$, mé: 9,9; $2,5 \mathrm{~cm}$, v: 0,8-1,1; 1,6 cm, Itsz: 2015.1.28. - ásatásból, 2. zacskó

19. Zsigmond-kori I. csoport, vakmérműves kályhacsempe előlapjának töredéke. Drapp színű, belül rózsaszín csíkkal, jól iszapolt, rosszul égetett, vékony falú, barnássárga színű mázzal. Téglalap alakú volt, 5 karéjos rozetta középen, hármas mérműprofillal. 6/b. típus vakmérmüves változata. $\mathrm{H}: 8 \mathrm{~cm}, \mathrm{sz}: 5,8 \mathrm{~cm}$, v: 0,5-0,6 cm, Itsz: 2015.1.12. - ásatásból, 7. zacskó

20. Zsigmond-kori I. csoport, vakmérműves kályhacsempe saroktöredéke. Drapp színű, rózsaszín csíkkal, jól iszapolt, rosszul égetett, sárgásbarna színű mázzal, belül használatra utaló koromnyomok Téglalap alakú volt, körben forgó halhólyagos minta, felső sarkokban térkitöltő 3 karéj. 1 pálcás mérmüprofil, nem ismert típus. $\mathrm{H}: 12,3 \mathrm{~cm}, \mathrm{sz}: 5,4 \mathrm{~cm}$, mé: $4,8 \mathrm{~cm}$, v: 0,7-1,1 cm, Itsz: 2015.1.13. - ásatásból, 7. zacskó

21. Zsigmond-kori I. csoport, kályhacsempe saroktöredéke. Drapp színű, részben rózsaszínre égett, jól iszapolt, rosszul égetett, sötétzöld színű, vastag mázzal, de a csempe belsejébe csak kissé folyt be. Csempe szélessége kb. $22 \mathrm{~cm}$ lehetett. Téglalap alakú csempe, dongás hátrésze, csak a sarok van meg, talán zárt elölap, de lehet félig áttört is. $\mathrm{H}: 14,2 \mathrm{~cm}$, sz: 4,5 cm, mé: 9,9 cm, v: 9-1,2 cm, Itsz: 2015.1.19. ásatásból, 6. zacskó

\section{Kályhaszemek}

22. Zsigmond-kori, hagyma alakú kályhaszem. Sötét rózsaszínü, jól iszapolt, jól égetett, felül sötétzöld máz, belül használatra utaló koromnyomok. Korongolási vonalakkal, csúcsos tetővel, a csúcsa alatt és a legszélesebb résznél 2-2 horony. M: $15 \mathrm{~cm}$, szá: 10,2 cm, v: 0,7-1 cm, Itsz: 2015.1.24.- ásatásból, 3. zacskó

23. Hagyma alakú kályhaszem töredéke. Világosbarna színű, homokkal soványított, jól iszapolt, jól égetett, belül használatra utaló koromnyomok. Csúcsos tetejü, a csúcs alatt egy horony. Á: $11,3 \mathrm{~cm}, \mathrm{~m}: 10,5 \mathrm{~cm}$, v: 0,5-0,6 cm, Itsz: 2015.1.14. - ásatásból, 7. zacskó
24. Hagyma alakú kályhaszem töredéke. Világosbarna színü, homokkal soványított, jól iszapolt, jól égetett, belül használatra utaló koromnyomok. Csúcsos tetejü, a csúcs alatt egy mély horony. $H: 9,5 \mathrm{~cm}, s z: 7 \mathrm{~cm}$, v: 0,4-0,6 cm, Itsz: 2015.1.25. - ásatásból, 7. zacskó

25. Hagyma alakú kályhaszem töredéke. Világosbarna színű, homokkal soványított, jól iszapolt, jól égetett, belül használatra utaló koromnyomok. Csúcsos tetejü, belül talán grafitozva lehetett. $\mathrm{H}: 5,6 \mathrm{~cm}$, sz: 6,4 cm, v: 0,5-0,6 cm, Itsz: 2015.1.20. - ásatásból, 3. zacskó

26. Szürke, redukált égetésű kályhaszem töredéke. Négyzetes alakú és félhengeres összeépített sarokcsempe. Sarok és beillesztett agyagcsík, egyenetlen kötélfonat bevagdalással. A kötélfonat imitáció két oldalán pecsétlőhengeres minta. Minta ismétlődési hossza $4,7 \mathrm{~cm}$, szélessége $0,6 \mathrm{~cm}$. Felülete sötétszürke, fakó, törésfelületén kicsit világosabb szürke, jól iszapolt, jól égetett. Méret: $22 \mathrm{~cm}$, négyzetes oldal $22+2 \mathrm{~cm}$ lehet, téglalap alakú oldal kb. $11 \mathrm{~cm}$. H: 22 $\mathrm{cm}$, mé: $8,8 \mathrm{~cm}$, v: 0,6-0,7 cm, Itsz: 2015.1.22.

27. Szürke, redukált égetésü kályhaszem töredéke. Négyzetes alakú és félhengeres összeépített sarokcsempe. Sarok és beillesztett agyagcsík, egyenetlen kötélfonat bevagdalással. Felülete sötétszürke, fakó, törésfelületén kicsit világosabb szürke, jól iszapolt, jól égetett. H: $14,6 \mathrm{~cm}$, mé: $6,7 \mathrm{~cm}$, v: 0,8 cm, Itsz: 2015.1.29.

28. Kisméretű tál alakú kályhaszem peremtöredékei, eredeti mérete $13 \times 13 \mathrm{~cm}$ lehetett. Sárga színü, homokkal soványított, jól iszapolt, jól égetett. $\mathrm{H}: 7,1$ cm, sz: 7,3 cm, v: 0,5-0,6 cm, Itsz: 2015.1.26.

29. Tál alakú kályhaszem saroktöredéke. Vörös színű, homokkal soványított, jól iszapolt, jól égetett, belső oldalán használatra utaló koromnyomok. H: 9,3 cm, mé: 11,6 cm, v: 0,9-1,1 cm, Itsz: 2015.1.23.

30. Fél kályhaszem aljtöredéke. Sárgásfehér színü, homokkal soványított, jól iszapolt, jól égetett. $\mathrm{H}$ : $7,6 \mathrm{~cm}, \mathrm{sz}:$ 9,4 cm, v: 0,8-0,9 cm, Itsz: 2015.1.21.

\section{Összefoglalás}

A Balatontól délre található Kereki várát (Fehérkő vára) 1336-ban említik először az írott források, de ennél korábbi régészeti lelet nem is került elő eddig. 1396-ban Marczali Miklós tulajdonába került, aki többek között erdélyi vajda és somogyi ispán is volt. Később birtokolta az Enyingi Török, a Báthori és a Perneszi család is. A várat feltehetően a 16. század első feléig használták. A vár területén nem folyt sok régészeti kutatás, mindöszsze Sági Károly végzett kisebb ásatást 1961-1962-ben. Sági Károly véleménye szerint akár három darab díszes kályha is állhatott a várban, valamint kettő egyszerübb szemes kályha.

Összesen 32 darab kályhacsempe és kályhaszem töredék került elő. A kályhacsempéket 12 különböző típusba tudtuk besorolni, bár a töredékek alapján nem mindig egyértelmű az azonosításuk. A csempék között találunk mesejelenetes, növényi ornamentikás, cseh oroszlánt és Sárkány Rendet ábrázoló típust is, de 
mérmúves és vakmérmúves darabok is vannak. A négyzetes alakú csempék és sarokcsempék a kályha kocka alakú alapját építhették fel. Efelett lehettek a mérműves, majd a vakmérmúves, téglap alakú csempék. A kályha kupoláját viszont a kor divatjának megfelelően hagyma alakú kályhaszemek díszítették. A kályhacsempék egy része a Zsigmond-kori I. csoporthoz sorolható. Ez a mühely 1390-1410 között müködhetett. A mühelyből kikerülő kályhacsempék nem csak a királyi palotában és vadászkastélyokban találhatók meg, hanem kolostorokban, bárók városi házaiban és vidéki rezidenciáin is. Kereki is utóbbiba sorolható, hiszen Marczali Miklós lehetett a kályha megrendelője. A kályhaszemeknek 4 különböző fajtáját tudtuk elkülöníteni, köztük szürke, tál alakú és világosbarna színü, hagyma alakú példányokat. A szürke színü kályhaszemekből a gótikus kályhák mintájára épültek fel kályhák a kevésbé reprezentatív helyiségekben feltehetően a 15. század második felében, míg a világosbarna-sárgás színü kályhaszemekből egy egyszerübb kályhát építhettek a 16. század elején.

\title{
Irodalom
}

BoLDIZSÁR P. 2003: Az esztergomi vár kora Zsigmond-kori kályhacsempe leletei. - Komárom-Esztergom Megyei Múzeumok Közleményei 10: 107-125.

ENGEL P. 1996: Magyarország világi archontológiája 1301-1457. I-II. Budapest, 1996.

HoLL I. 1958: Középkori kályhacsempék Magyarországon I. Az udvari központok műhelyei és hatásuk a vidéki fazekasságra (XIV. század - XV. század közepe). - Budapest Régiségei XVIII: 211-300.

HoLL I. 1971: Középkori kályhacsempék Magyarországon II. - Budapest Régiségei XXII: 161-207.

HoLL I. 1985: Dunántúli kályhacsempék (Udvari műhelyek szállítása a 15. században). - Veszprém Megyei Múzeumok Közleményei 17: 209-220.

HoLL I. 1990: Középkori kályhacsempék Magyarországon IV. Archaeologiai Értesítő 117: 52-76.
HOLL I. 2002: Középkori kályhacsempék Magyarországon VIII. A Zsigmond-kori I. csoport mintakincsének és kronológiájának kérdéséhez. - Budapest Régiségei XXXV: 357-380.

HoLL I. 2010: Középkori kályhacsempék Magyarországon XI. Címeres reprezentáció. - In: Benkő Elek és Kovács Gyöngyi (szerk.): A középkor és a kora újkor régészete Magyarországon I-II. Budapest, 2010. 709-757

KopPÁNY T. És SÁGI K. 1967: A kereki Fehérkő vár története. Somogyi Múzeum 9. Kaposvár, 1967.

Koppány T. 1993: A Balaton környékének műemlékei. Művészettörténet - Müemlékvédelem III. Budapest, 1993.

KovÁcs, B. 2014: Von der ungarischen Königsburg zur osmanischen Grenzbefestigung - die Burg Gesztes. - Burgen und Schlössen. Zeitschrift für Burgenforschung und Denkmalpflege 55/4: 233-241.

\section{Different types of stove tiles from the Kereki castle}

\author{
EDIT KOCSIS and MÁTÉ VARGA
}

The castle of Kereki (Fehérkő Castle), located south of Lake Balaton, was first mentioned in known written sources in 1336, and also no archaeological finds dating back earlier have been unearthed so far. In 1396 it became the property of Miklós Marczali, who, among others, held the title of the Transylvanian voivode and the comes of Somogy. It was later owned by the Enyingi Török, the Báthori and the Perneszi families. The castle was probably used until the first half of the 16th century. There was not much archaeological excavation in the area of the castle, only Károly Sági carried out a small excavation in 1961-1962. According to Károly Sági, up to three ornate stoves could have stood in the castle, as well as two simpler stoves.

A total of 32 stove tiles fragments were found, including types that the Hungarian terminology calls "eyes". The tiles could be classified into 12 different types, although their identification is not always clear based on the fragments. Among the tiles we can find pieces depicting scenes from fairytales, types with plant ornaments, there are pieces depicting the Czech lion and the
Order of the Dragon, but there are also some decorated with open and blind traceries. Square tiles and corner tiles could have built the cube-shaped base of the stove. Above them were the rectangular tiles adorned with open and blind traceries. The dome of the stove, on the other hand, was decorated with onion-shaped stove tiles (the "eyes"), adapted to the fashion of the era. Some of the stove tiles belong to Group I of the Sigismund era. This workshop may have operated from 1390 to 1410 . The stove tiles coming out of the workshop can be found not only in royal residences, but also in monasteries, town houses or rural residences of barons. Kereki is one of the latter, as Miklós Marczali may have been the purchaser of the stove. We were able to distinguish 4 different varieties of the so-called "stove eyes", including gray, bowl-shaped, and light brown, onion-shaped examples. Of the gray tiles, stoves in the less representative rooms were built after the outline of Gothic stoves, presumably in the second half of the 15th century; while a simpler stove of light brown-yellow tiles could be built in the early 16th century. 